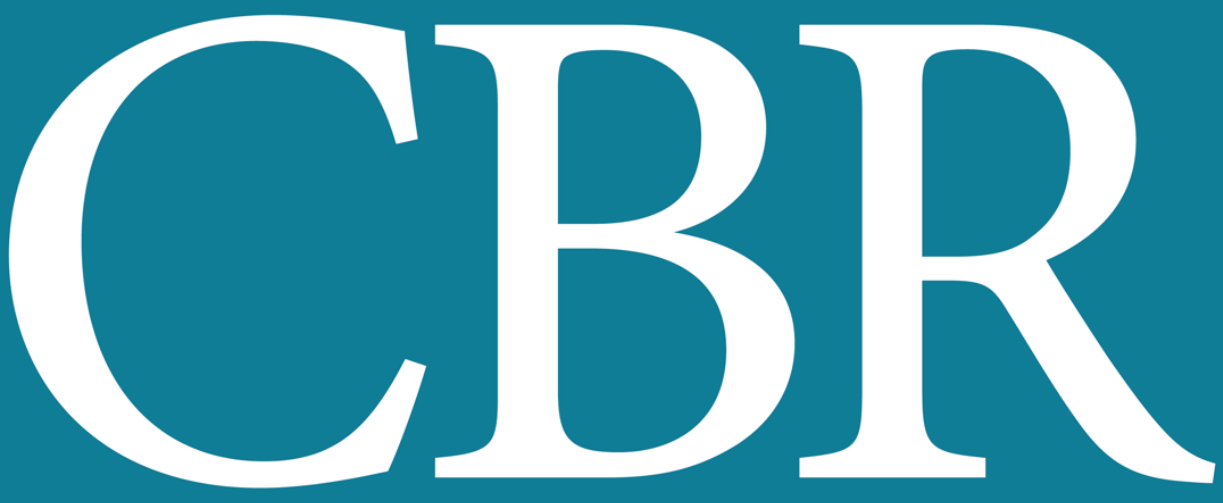

INTERNATIONAL JOURNAL OF CANCER AND BIOMEDICAL RESEARCH

https://jcbr.journals.ekb.eg

Editor-in-chief

Prof. Mohamed Labib Salem, PhD

Ameliorating effects of rosemary and costus on blood-associated toxicity in Ehrlich-bearing mice treated with cisplatin

Yousry E. El-Bolkiny, Mohamed L. Salem, Sabry A. El-Naggar and Fatma R. El-Sharkawy 


\title{
Ameliorating effects of rosemary and costus on blood-associated toxicity in Ehrlich-bearing mice treated with cisplatin
}

\author{
Yousry E. El-Bolkiny, Mohamed L. Salem, Sabry A. El-Naggar and Fatma R. El-Sharkawy \\ Zoology Department, Faculty of Science, Tanta University, Tanta, Egypt
}

\section{ABSTRACT}

Background: Rosemary (ROLE) and costus (SLRE) have been established to show antioxidant effects. Aim: This study aimed to evaluate the ameliorating effects of ROLE and SLRE to the side-effects induced by cisplatin (CIS) in tumor-bearing mice. Materials and Methods: Extracts of ROLE and SLRE were examined for their phytochemical activities. To ecaluate their anti-tumor effects, mice were inoculated intraperitoneally (i.p.) with $2.5 \times 10^{5}$ Ehrlich ascites carcinoma (EAC) and then treated i.p. with CIS (dose????) at days 3-7 and with ROLE (dose) or SLRE (dose) at days 3-14. Mice were sacrificed on day 14 for CBC and T-cell analyses. Results: Phytochemical analysis revealed that both ROLE and SLRE showed similar antioxidant activities. Treatment of EAC-bearing mice with CIS induced antitumor efficacy of about $90 \%$. Treatment with CIS in combination of ROLE or SLRE did not further enhance the the antitumor activity of CIS. However, co-administration of ROLE or SLRE with CIS increased significantly the antitumor efficacy of CIS. Flow cytometric analysis showed that the numbers of $\mathrm{CD}^{+}$and $\mathrm{CD}^{+} \mathrm{T}$ cells were decreased in EAC bearing mice after treatment with CIS. Treatment with both ROLE and SLRE improved the number of these cells. Conclusion: Combinatorial treatment with rosemary and costus can enhance the antitumor activity of CIS while lower its side effects.

Keywords: CBC, Cisplatin, Costus, Ehrlich Ascites, Lymphocytes, Rosemary, Tumor

\section{ARTICLE INFO}

Article history

Received: July 6, 2020

Revised: August 25, 2021

Accepted: August 25, 2021

Correspondence to

Fatma R. El-Sharkawy

Zoology Department, Faculty of Science,

Tanta University, Tanta, Egypt

Email:

fatma.elsharkawy@science.tanta.edu.eg

Copyright

(C) 2021 YE El-Bolkiny, ML Salem, SA EINaggar and FR El-Sharkawy. This is an Open Access article distributed under the Creative Commons Attribution License, which permits unrestricted use, distribution, and reproduction in any medium, provided the original work is properly cited.

Editor-in-Chief: Prof. M.L. Salem, PhD - Article DOI: 10.21608/jcbr.2021.84374.1219

\section{INTRODUCTION}

Cancer is one of the most health problems worldwide; breast cancer is the most frequent among women. Advanced breast cancer is considered incurable under currently available therapies with distant organ metastases (Seidler \& Huber, 2020). However, chemotherapy for breast cancer has several bad side effects (Sorsa et al., 1985). Despite early detection and treatment over the last 10 years caused a significant decrease in mortality, the incidence of breast cancer continues to rise for multifactor including family history (Britt et al., 2020). Presently, patients are treated with traditional therapies such as surgery, chemo and radiotherapy, and new types of treatment such as immune and targeted therapy, depending on the type and stage of cancer (Baudino, 2015). Chemotherapy treatments are used to vigorously inhibit the development of malignant cells with cancer agents and to produce palliative relief and symptomatic relaxation. Chemotherapy is usually done in a cyclic duration, weekly or biweekly sessions; one of them is cisplatin (Alam et al., 2018).

Cisplatin is a potent chemotherapeutic drug used to treat a variety of solid tumours, including testicular, bladder, lung, head and neck cancers (Schoch et al., 2020). Its clinical efficacy is, however, limited by serious effects specifically tumour cell resistance, as well as dose-limiting nephrotoxicity (Oun et al., 2018). Cisplatin is one of the most popular and commonly utilized medications for treating various solid malignancies. The anti-cancer activity of Cisplatin has occurred in various ways; the most accepted one is generating DNA lesions through interaction with purine DNA bases and the activation of several signal transduction processes that ultimately lead to apoptosis. However, two essential challenges of Cis side effects are drug resistance and 
effectiveness (Ghosh, 2019). In the time of the clinical value of Cis is limited by its nephrotoxic and cardiotoxic side effects, other combined drugs such as cyclophosphamide can alleviate these toxicity effects (El-Bolkiny, 2006). Therefore, Cis side effects prevention is one of the main problems of cancer therapy (Kailnde et al., 2020).

Research in different parts of Africa has reported a number of medicinal plants for cancer therapy (Alenzi et al., 2010). For example, a total of 151 medicinal plants were used to treat different types of cancer, such as breast, liver, prostate, stomach and brain cancer (Agyare et al., 2018). An in vitro study performed by Abdel-hamid et al. (2017) showed that Khoshia indica had anti-tumor activity in hepG $\mathrm{G}_{2}$ cell line. In the same line, two medicinal plants, rosemary (Rosemarinus officinalis) and costus (Saussurea lappa) have plenty of biological activities. Some studies have shown that Rosemary is actively involved in the prevention and treatment of cancer. The antiproliferative activity of its extract was due to three main active components; Carnosol (CS), Carnosic acid (CA) and Rosmarinic acid (RA), which can enhance the anti-proliferative activity of Cis (Tai et al., 2012). In the same line, Costus is a member of Asteraceae, and was reported as an aromatic, permanent seasonal plant that is rich in antioxidant, anti-diabetic, anti-hepatotoxic, anti-tumor, antiinflammatory and anti-microbial ingredients. Worldwide, costus is widely used for the treatment of different types of disturbances such as diarrhea, tenesmus, dyspepsia, vomiting and inflammation in various indigenous systems (Bolkiny et al., 2019). They showed that costus could restore euthyroid status after treatment of hypo- and hyper-thyroid mice with costus root extract. To reduce side effects and adverse toxicity of Cis, we hypothesized that the oral administration of R. officinalis and S. lappa with their adverse biological activities may affect or modulate the toxicity in blood elements and other related side effects induced by $\mathrm{Cis}$ in Ehrlich - bearing mice. Accordingly, this work aimed to investigate the role of rosemary and costus alone or combined in the amelioration of CP-induced adverse blood toxicity, and their impacts on Cis efficacy. This work was extended to assess therapeutic efficacy of rosemary and costus on health important functions such as tumor development, $\mathrm{CBC}$ and splenocyte count.

\section{MATERIAL AND METHODS Preparation of plant extracts}

Both dry leaves of rosemary and roots of costus were purchased from the local market of Alexandria city, Egypt. The plant materials were identified and authenticated by a taxonomist at the Botany Department, Faculty of Science, Tanta University. Leaves of rosemary and root of costus were crushed and the powder $(50 \mathrm{~g}$ ) was mixed vigorously with $500 \mathrm{~mL}$ of $80 \%$ ethanol to get a hydro-alcoholic extract, and then filtered. The solvent was dried under air condition. Both extracts were weighed and suspended in $0.9 \%$ sterile saline for further processing (El-Naggar et al., 2016).

\section{Phytochemical analysis}

The phytochemical analysis of each plant extract was performed using the metal chelation capacity (MCC), total antioxidant capacity (TAC), scavenging activity (DPPH) and total phenolic content (TPC). The MCC assay was carried out based on the method of Minotti \& Aust (1987). The quantitative determination of TAC was done by spectrophotometric approach of Prieto et al. (1999). The spectrophotometric DPPH assay was done according to Shimada et al. (1992) based on absorption reduction monitoring of DPPH radical in the presence of antioxidants. Determination of TPC was performed as described by Velioglu et al. (1998) using Folin-C reagents and the absorbance was measured at $725 \mathrm{~nm}$ compared to a gallic acid calibration curve.

\section{Chemicals}

Cisplatin (Cis-diamminedichloroplatinum II) was attained from El-Hekma Company, Cairo in a vial containing $50 \mathrm{mg}$ Cis $/ 50 \mathrm{ml}$ solvent. DPPH $(2,2$ diphenyl-1-picrylhydrazyl) was purchased from Sigma Aldrich Co. (St Quentin Fallavier, France). Ammonium chloride potassium (ACK) buffer was prepared in our laboratory and used to lyse RBCs in the blood and spleen samples. Normal saline was also prepared (0.9\%) and the $\mathrm{pH}$ was adjusted to 7 and used for suspending and washing immune cells. Absolute ethyl alcohol was purchased from El-Gomhoria Company, Tanta, Egypt. 


\section{Ehrlich ascites cell (EAC) collection}

Ehrlich Ascites Carcinoma (EAC) cell line was originally obtained from the National Cancer Institute (Cairo University, Egypt). EAC cells were inoculated by serial IP administration of $0.25 \times 10^{6}$ cells $/ 0.2 \mathrm{ml}$ saline in CD1 mice. Donor CD1 mice were left for 10 days until ascites is formed. EAC cells were harvested under sterile conditions then purified to be used later for in vivo and in vitro studies (Geran et al. 1972).

\section{Animals}

Ninety healthy adult female Swiss albino mice (average weight of 18-20 g) were obtained from the Animal facility of Cairo University, Egypt. Mice groups were maintained in suitable cages with standard hygienic circumstances, 12:12 h light/dark cycle and were frequently provided with a balanced commercial diet and free access to water. All the experiments were done in compliance with the guiding principles for the care and use of the laboratory animals at the Faculty of Science, Tanta University that approved the experimental design under coding number (IACUC-SCITU-0099).

\section{Experimental design}

Mice were randomly divided equally into six groups $(\mathrm{Gp} / \mathrm{n}=15)$. Gp 1 was kept as the negative control. Mice in Gp 2 were IP inoculated with $\left(0.25 \times 10^{6} /\right.$ mouse $)$ of EACs and was kept as the positive control. Gp 3 was IP injected daily for 5 days with cisplatin from D3 to D7. Mice in Gps 4 - 6 were IP injected with EAC $\left(0.25 \times 10^{6}\right)$ followed by Cis concomitant with ROLE alone in case of Gp 4, and with SLRE alone in case of $\mathrm{Gp} 5$ and with two herbal extracts in Gp 6 (Figure 1). Based on the above protocol plan, mice were inoculated with $0.25 \mathrm{X}$ $10^{6}$ EAC cells on day zero. EAC group treated every other day with cisplatin $(2 \mathrm{mg} / \mathrm{kg}$ ) three times until day 7 (El Kholy et al., 2016). In a concurrent with $\mathrm{Cis}$, the two plant extracts were administrated orally until day 14 at a dose level of $100 \mathrm{mg} / \mathrm{kg}$.

\section{Sample collection}

After 14 days of injection, 10 mice from each group were used for blood sampling from retroorbital venous plexus under anaesthesia using heparinized microhematocrit tubes (Prasanna et al., 2017).
Each blood sample was collected in clean tubes containing disodium salt of EDTA (Abdallah et al., 2020) for hematological examination $(n=6) /$ group.

\section{EAC criteria}

The total volume of tumor $/ \mathrm{ml}$ and total count of tumor cells/total tumor volume were determined using morphological criteria for the EAC tumor development as described by Kunimura et al. (1998).

\section{Weight change}

The body weight of mice was determined at the start and the end of each experiment period and recorded as initial weight $\left(\mathrm{Wt}_{\mathrm{i}}\right)$ and final weight $\left(\mathrm{Wt}_{\mathrm{f}}\right)$, respectively. At dissection, the relative weights of vital internal organs were also monitored. The percentage change in the body and internal organ's weights of mice were calculated according to El-Bolkiny et al. (2020).

\section{CBC profile}

The total and differential leukocytic count was estimated using an automated instrument for complete blood counts (VetScan $\mathrm{HM}^{\mathrm{TM}}$ Hematology System, Abacus, Germany). The number of blood samples were used to determine $C B C$ including $R B C s$, Platelets, hemoglobin content $(\mathrm{Hb} \mathrm{g} / \mathrm{dl}), \mathrm{WBCs}$ and its differential count were evaluated.

\section{Flowcytometric analysis}

The principle of the flow cytometric procedure is to generate specific multi-parameter data for particles and cells with diameter ranges between $0.5 \mu \mathrm{m}$ and $40 \mu \mathrm{m}$. Before the optimally focused light source is removed, cells are hydro-dynamically concentrated on a sheath of the phosphate buffer saline (Talbot, 1993). Flow cytometric analysis of $\mathrm{CD}^{+}$and $\mathrm{CD}^{+} \mathrm{T}$ cells was done with mouse anti-CD4+ FITC (GK 1.5 clone) and mouse anti-CD8 ${ }^{+}$FITC (clone 53-6.7) for $\mathrm{CD}^{+}$and $\mathrm{CD}^{+}{ }^{+} \mathrm{T}$ cells that infiltrated EAC tumours (BD Biosciences).

\section{Preparation of spleen cell suspensions and splenocytes count}

The cell suspensions of the spleen were prepared according to Salem et al. (2007). Cells were washed twice; RBCs were lysed with ACK and the remaining cells were again washed 3 
times and counted. The cell viability was determined by Trypan blue exclusion and consistently exceeded $90 \%$ (Salem et al., 2020).

\section{Statistical analysis}

The obtained data were expressed as means \pm standard deviation $(X \pm S D)$. Differences among groups were determined using one-way ANOVA followed by Dunnette test or Student's $t$-test where appropriate. Significant differences between means were indicated by $p$-values < 0.05. All statistical analyses were performed using SPSS statistical version 16 software package (SPSS ${ }^{\circledR}$ Inc.32., USA).

\section{RESULTS}

\section{Phytochemical properties of rosemary and costus}

As shown in Table 1, the extractive value (21.432 g) of Saussurea lappa (SLRE) was higher than Rosemarinus officinalis (ROLE), which offered the least yield (16.894 g) from an initial weight of $50 \mathrm{~g}$ dry powder for both plants in hydro-ethanolic solution. The percentages of metal scavenging capacity at $(10 \mathrm{mg} / \mathrm{ml}) /$ tested extract of ROLE and SLRE were found to be $78.33 \%, 43.33 \%$, respectively (Figure $2 \mathrm{a}$ ). These findings revealed that ROLE has a potent antioxidant activity (17.38 \%) than SLRE (15.26 $\%)$ as shown in Figure (2b). The ethanol extract of SLRE showed higher DPPH radical scavenging activity (32.25\%) than ROLE (19.30\%) as in Figure 2c.

The total phenolic contents (TPC) in both extracts are presented in figure (1d). Results were expressed as mg GAE/g of extract using a gallic acid standard curve. The amounts of phenols were 156.32 and 146.06 in ROLE and SLRE mg/GAE, respectively. Therefore, the ethanol extract of ROLE has a high content of TPC than SLRE.

\section{Effects of treatment with rosemary and costus on the body weigh}

The current results showed that the change in the body weight and the relative organ's weights were monitored as an indirect index for tumor progression in this model and the role of treatments in amelioration. Data in Figure 3 shows the changes in the body weights (BW) of mice in all experimental groups. There is a little increase $(10.58 \%)$ in the final BW of control mice compared to the initial weight. This increase reached $37.7 \%$ in mice bearing EAC (Gp2) compared to the initial BW. The treatment of EAC-mice with Cisplatin alone reduced the tumor growth by $2.62 \%$ compared to the initial BW of the same group. The concomitant administration of ROLE or SLRE with Cis further reduced the tumor growth in EAC-mice (Gp4 and Gp5) by $18.8 \%$ and $5.17 \%$, respectively compared to their initial weights; ROLE was more significant. Administration of combined ROLE and SLRE with Cis led to a marked effect, where tumor growth reduced by $7.45 \%$ compared to the initial weight of Gp6.

Table 2 shows the relative weight (RLW) of the most vital organs such as the liver, kidneys, spleen and heart of mice in all experimental groups. Subsequently, the RLW of the liver in EAC-bearing mice treated with a combination of Cis/ROLE/SLRE showed a significant increase compared to the control. Moreover, this RLW in EAC-mice treated with Cis/SLRE showed a significant decrease compared to EAC-mice alone. EAC-mice that were treated with $\mathrm{Cis}$, or treated with ROLE gave no significant changes in RLW of the liver compared to EAC alone. The RLW of kidneys in EAC-mice was significantly decreased compared to the naive group. In the interim, RLW of kidney in EAC-mice received a combination of EAC/Cis/ROLE/SLRE was significantly increased compared to EACbearing mice.

A significant increase in RLW of spleen resulted in EAC-mice treated with a combination of Cis/ROLE/SLRE compared to EAC-mice alone. No significant changes in this RLW of the other groups resulted when compared to EAC-mice. Regarding RLW of the heart, EAC-mice showed a significant decrease compared to the naive group. While the EAC-mice treated with Cis/ROLE/SLRE showed no significant changes in this RLW compared to the control group. It was observed that EAC-mice received Cis, Cis/ROLE or Cis/SLRE have no significant changes in their hearts RLW compared to EAC-mice.

\section{Effects of treatment with rosemary and costus on EAC cell numbers}

Results in Figure 4 showed a significant increase in the tumor cell count in EAC-mice when 
compared to other groups. Whereas mice groups treated with Cis/ROLE, Cis/SLRE, or Cis/ROLE/SLRE showed no significant changes compared to EAC-mice (Gp3) treated with Cis alone. In addition, a significant increase in the tumor volume in EAC-mice when compared to other groups based on the data of tumor cell count. As shown in figure (5), groups that treated with Cis/ROLE, Cis/SLRE, or Cis/ROLE/SLRE have no significant changes in the tumor volume compared to EAC-mice treated with Cis alone (Gp3). Accordingly, treatment of EAC-mice with cis reduced significantly the tumor cells count and tumor volume, while treatment with ROLE or SLRE alone or in combination concomitant with $\mathrm{Cis}$ did not further change tumor count and tumor volume.

\section{Effects of treatment with rosemary and costus on splenocytes count}

The obtained data in figure (6) showed that EAC-mice treated with Cis have a significant decrease in splenocytes count compared to EAC-mice alone (Gp2). In the meantime, data showed no significant changes in EAC/Cis/SLRE (Gp5) or EAC/Cis/ROLE/SLRE (Gp6). Posttreatment of EAC-mice with Cis/ROLE or Cis/SLRE resumed the value of splenocytes count; EAC/Cis/ROLE/SLRE have a marked effect near to that of the naive group (Gp1). Therefore, the treatment of tumour-bearing mice with Cis significantly decreased splenocytes count and the concurrent treatment with both combined plant extracts restored normal splenocyte count.

\section{Effects Effects of treatment with rosemary and costus on CBC}

Results in Table 3 showed that there were no significant changes in RBCs and platelets count and PCV \% in EAC-mice groups that received ROLE or SLRE single or combined compared to EAC-mice alone (Gp2). Furthermore, there was no significant change in $(\mathrm{Hb})$ concentration in groups that received $\mathrm{Cis}$ alone or combined with ROLE or SLRE compared to EAC-mice alone. Moreover, results showed that EAC inoculation led to a significant increase in WBCs count compared to the naïve control. Whereas mice groups that treated with Cis alone or combined with ROLE or SLRE have no significant change in total WBCs count (Table 3) compared to EAC-mice alone (Gp2). Meanwhile, the percentage of neutrophils was highly increased significantly in EAC-mice (Gp2) compared to the naïve group. The treatment of tumorized mice with cisplatin increased the percentage of neutrophiles compared to EAC alone, while administration of either ROLE or SLRE concomitant with Cis decreased neutrophils percentage compared to $\mathrm{EAC} / \mathrm{Cis}$ (Gp3). On the other hand, the combined form of EAC/Cis/ROLE/SLRE improved markedly the neutrophils percentage to be around normal compared to the naïve group (Table 4). There is no significant change in eosinophils and lymphocytes in groups that were treated with ROLE or SLOE alone or in combination compared to EAC-mice alone (Gp2). Treatment with EAC/Cis/ROLE (Gp4) increased the monocyte count when compared to $\mathrm{EAC} / \mathrm{Cis}$ (Gp3). Treatment of EAC-mice with $\mathrm{Cis}$ and SLRE alone or combined with SLRE showed no significant changes when compared to EACmice alone (Gp2).

Effects of treatment with rosemary and costus on the numbers of $\mathrm{CD}^{+}$and $\mathrm{CD} 8^{+}$cells

The possible effect of the cisplatin and plant extracts on the phenotypic expression of Tlymphocytes subsets of helper (CD4 ${ }^{+}$T-cells) has been investigated by flow cytometry. As shown in Table (5) and Figure 7, EAC induction in mice led to a very significant increase in both subsets; $C D 4$ and CD8 compared to naïve mice. Treatment of EAC-mice with Cis significantly reduced the expressions of helper $\mathrm{CD}_{4}^{+}$and $\mathrm{CD}^{+}{ }^{+} \mathrm{T}$-cell subsets compared to EAC-mice alone. Administration of $\mathrm{EAC} / \mathrm{Cis}$-treated mice with combined extracts further reduced the expressions of helper $\mathrm{CD}^{+}$and $\mathrm{CD}^{+} \mathrm{T}$-cell subsets compared to $\mathrm{EAC} / \mathrm{CIS}$ group.

In addition, the possible therapeutic effect of both extracts on the phenotypic expression of T-lymphocytes subsets of cytotoxic $\mathrm{CD}^{+} \mathrm{T}$-cell has been investigated by flow cytometry (Fig. 8). Both $\mathrm{CD} 4^{+}$and $\mathrm{CD} 8^{+} \mathrm{T}$-cell subsets were shown with significant changes compared to both negative and positive control groups. It becomes clearer that treatment with both plant extracts showed significant improvement in the immune response compared to $\mathrm{EAC} / \mathrm{CIS}$ group. 
Table 1. The amounts of yield extract from $50 \mathrm{~g}$ of both rosemary (ROLE) and costus (SLRE) dry powder

\begin{tabular}{|c|c|c|}
\hline Medicinal plant & Initial weight & Yield (\%) \\
\hline ROLE & $50 \mathrm{~g}$ & $16.894 \%$ \\
\hline SLRE & $50 \mathrm{~g}$ & $21.432 \%$ \\
\hline
\end{tabular}

ROLE: Rosemarinus officinalis leaves extract, SLRE: Saussurea lappa root extract

Table 2. The relative weight of liver (RLW), kidney (RKW), spleen (RSW) and heart (RHW) of mice in all experimental groups

\begin{tabular}{|c|c|c|c|c|}
\hline Gps / treatments & RLW $(X \pm$ SD) & RKW $(X \pm$ SD) & RSW $(X \pm S D)$ & RHW $(X \pm$ SD) \\
\hline Gp1: Cont. & $5.14^{\mathrm{bc}} \pm 0.86$ & $1.09^{\mathrm{ab}} \pm 0.22$ & $0.90^{\mathrm{ab}} \pm 0.26$ & $0.69^{\mathrm{a}} \pm 0.12$ \\
\hline Gp2: EAC-bearing mice & $5.77^{\mathrm{ab}} \pm 0.23$ & $0.79^{\mathrm{c}} \pm 0.13$ & $0.53^{\mathrm{cd}} \pm 0.10$ & $0.27^{\mathrm{c}} \pm 0.05$ \\
\hline Gp3: EAC/Cis. & $6.27^{\mathrm{ab}} \pm 0.42$ & $1.19^{\mathrm{ab}} \pm 0.17$ & $0.87^{\mathrm{abc}} \pm 0.17$ & $0.48^{\mathrm{abc}} \pm 0.16$ \\
\hline Gp4: EAC/Cis./ROLE & $5.13^{\mathrm{bc}} \pm 0.52$ & $1.12^{\mathrm{ab}} \pm 0.07$ & $0.77^{\mathrm{bc}} \pm 0.07$ & $0.59^{\mathrm{ab}} \pm 0.21$ \\
\hline Gp5: EAC/Cis./SLRE & $4.44^{\mathrm{c}} \pm 0.50$ & $0.97^{\mathrm{bc}} \pm 0.18$ & $0.38^{\mathrm{d}} \pm 0.05$ & $0.44^{\mathrm{bc}} \pm 0.07$ \\
\hline Gp6: EAC/Cis/ROLE/SLRE & $6.27^{\mathrm{a}} \pm 1.26$ & $1.28^{\mathrm{a}} \pm 0.26$ & $1.10^{\mathrm{a}} \pm 0.35$ & $0.63^{\mathrm{ab}} \pm 0.16$ \\
\hline F-Value & $7.047^{*}$ & $6.940^{*}$ & $12.200^{*}$ & $8.774^{*}$ \\
\hline p-Value & $<0.001^{*}$ & $<0.001^{*}$ & $<0.001^{*}$ & $<0.001^{*}$ \\
\hline
\end{tabular}

RLW: Relative Liver weight, RKW: Relative kidney weight, RSW: Relative Spleen weight, RHW: Relative Heart weight. Data are expressed as means \pm SD. The symbols $(a, b, c$.) indicate a significant change at $p<0.05$ compared with the control. Symbols that share the same letters do not show any significance.

Table 3. Effects of ROLE and SLRE, alone or combined, on CBC of EAC-bearing mice treated with Cis.

\begin{tabular}{|c|c|c|c|c|}
\hline Gps / treatments & Hb (g/dl) $(\mathbf{X} \pm \mathbf{S D})$ & RBCs $\left(\times 10^{\mathbf{6}} / \boldsymbol{\mu l}\right)(\mathbf{X} \pm \mathbf{S D})$ & PCV $(\%)(\mathbf{X} \pm \mathbf{S D})$ & Plt $\left(\times 10^{\mathbf{3}} / \boldsymbol{\mu l}\right)(\mathbf{X} \pm \mathbf{S D})$ \\
\hline Gp1: Cont. & $12.90^{\mathrm{a}} \pm 0.53$ & $9.11^{\mathrm{a}} \pm 0.54$ & $43.62^{\mathrm{a}} \pm 3.31$ & $665.0^{\mathrm{a}} \pm 131.0$ \\
\hline Gp2: EAC-bearing mice & $11.80^{\mathrm{a}} \pm 1.18$ & $8.48^{\mathrm{a}} \pm 0.79$ & $44.69^{\mathrm{a}} \pm 4.81$ & $574.3^{\mathrm{a}} \pm 4.16$ \\
\hline Gp3: EAC/Cis. & $13.0^{\mathrm{a}} \pm 0.44$ & $9.39^{\mathrm{a}} \pm 0.98$ & $42.50^{\mathrm{a}} \pm 1.76$ & $649.0^{\mathrm{a}} \pm 319.1$ \\
\hline Gp4: EAC/Cis./ROLE & $13.83^{\mathrm{a}} \pm 1.63$ & $10.17^{\mathrm{a}} \pm 1.68$ & $47.42^{\mathrm{a}} \pm 9.12$ & $562.7^{\mathrm{a}} \pm 318.2$ \\
\hline Gp5: EAC/Cis./SLRE & $13.47^{\mathrm{a}} \pm 1.42$ & $9.39^{\mathrm{a}} \pm 0.73$ & $41.63^{\mathrm{a}} \pm 3.92$ & $816.0^{\mathrm{a}} \pm 46.36$ \\
\hline Gp6: EAC/Cis/ROLE/SLRE & $11.90^{\mathrm{a}} \pm 1.15$ & $8.36^{\mathrm{a}} \pm 0.58$ & $43.82^{\mathrm{a}} \pm 3.75$ & $715.3^{\mathrm{a}} \pm 148.4$ \\
\hline F-Value & 1.542 & 1.437 & 0.486 & 0.652 \\
\hline p-Value & 0.249 & 0.280 & 0.781 & 0.666 \\
\hline
\end{tabular}

Hb: Hemoglobin, RBCs: Red blood cells, PCV: packed cell volume, Plt: platelets. Data are expressed as means \pm SD. The symbols $(a, b, c$.) indicate a significant change at $p<0.05$ compared with the control. Symbols that share the same letters do not show any significance.

Table 4. Effects of ROLE and SLRE, alone or combined, on total WBCs and leucocytes differential counts of EAC-bearing mice treated with cisplatin.

\begin{tabular}{|c|c|c|c|c|c|}
\hline \multirow[b]{2}{*}{ Gps / treatments } & \multirow{2}{*}{$\begin{array}{c}(W B C s) \times 10^{3} / \mu l \\
(X \pm S D)\end{array}$} & \multicolumn{4}{|c|}{ Differential leukocytes count } \\
\hline & & $\begin{array}{c}\text { Neutro. (\%) } \\
(X \pm S D)\end{array}$ & $\begin{array}{c}\text { Eosino (\%) } \\
(X \pm S D)\end{array}$ & $\begin{array}{c}\text { Lympho (\%) } \\
(X \pm S D)\end{array}$ & $\begin{array}{c}\text { Mono (\%) } \\
(X \pm S D)\end{array}$ \\
\hline Gp1: Cont. & $8.71^{\mathrm{a}} \pm 2.29$ & $5.3^{c} \pm 1.55$ & $3.0^{\mathrm{a}} \pm 0.50$ & $78.7^{a} \pm 15.65$ & $4.6^{b} \pm 0.60$ \\
\hline Gp2: EAC-bearing mice & $20.3^{\mathrm{a}} \pm 4.18$ & $19.4^{b} \pm 3.20$ & $3.37^{a} \pm 0.55$ & $77.7^{a} \pm 11.34$ & $4.6^{b} \pm 0.58$ \\
\hline Gp3: EAC/Cis. & $7.8^{\mathrm{a}} \pm 1.17$ & $28.4^{\mathrm{a}} \pm 3.33$ & $2.9^{\mathrm{a}} \pm 1.34$ & $69.7^{a} \pm 15.72$ & $2.4^{\mathrm{ab}} \pm 1.23$ \\
\hline Gp4: EAC/Cis./ROLE & $6.2^{\mathrm{a}} \pm 1.07$ & $15.8^{\mathrm{b}} \pm 2.16$ & $4.2^{\mathrm{a}} \pm 1.92$ & $70.2^{\mathrm{a}} \pm 2.77$ & $8.2^{\mathrm{a}} \pm 2.19$ \\
\hline Gp5: EAC/Cis./SLRE & $6.3^{a} \pm 1.60$ & $20.1^{\mathrm{b}} \pm 1.57$ & $4.0^{\mathrm{a}} \pm 1.55$ & $75.0^{\mathrm{a}} \pm 5.40$ & $5.6^{\mathrm{ab}} \pm 1.10$ \\
\hline Gp6: EAC/Cis/ROLE/SLRE & $8.5^{\mathrm{a}} \pm 1.33$ & $6.70^{c} \pm 2.43$ & $3.33^{\mathrm{a}} \pm 1.04$ & $84.1^{\mathrm{a}} \pm 2.34$ & $5.6^{\mathrm{ab}} \pm 0.52$ \\
\hline F-Value & 1.507 & $37.551^{*}$ & 0.526 & 0.822 & $3.684^{*}$ \\
\hline p-Value & 0.259 & $<0.001^{*}$ & 0.753 & 0.557 & $0.030^{*}$ \\
\hline
\end{tabular}

Data are expressed as means \pm SD. The symbols $(a, b, c$. $)$ indicate a significant change at $p<0.05$ compared with the control. Symbols that share the same letters do not show any significance. 
Table 5. Effects of ROLE and SLRE on phenotypic expression of $\mathrm{CD} 4^{+} \%$ and $\mathrm{CD} 8^{+} \%$ in EAC-bearing mice treated with Cis

\begin{tabular}{|l|c|c|}
\hline Gps / treatments & CD4+ (\%) & CD8+ (\%) \\
\hline Gp1:Cont. & $16.2^{\mathrm{a}} \pm 2.3$ & $11.1^{\mathrm{a}} \pm 0.88$ \\
\hline Gp2: EAC- alone & $74.23^{\mathrm{b}} \pm 14.09$ & $65.93^{\mathrm{b}} \pm 14.93$ \\
\hline Gp3: EAC/Cis. & $24.43^{\mathrm{c}} \pm 1.91$ & $34.83^{\mathrm{c}} \pm 0.5$ \\
\hline Gp6: EAC/CIS/ROLE/SLRE & $20.33^{\mathrm{a}} \pm 6.55$ & $17.1^{\mathrm{a}} \pm 1.34$ \\
\hline P-value & 0.249 & 0.557 \\
\hline
\end{tabular}

$C D$ : Cluster of Differentiation, Data are expressed as means \pm SD. The symbols $(a, b, c$.) indicate a significant change at $p \leq$ 0.05 compared with the control. Symbols that share the same letters do not show any significance.

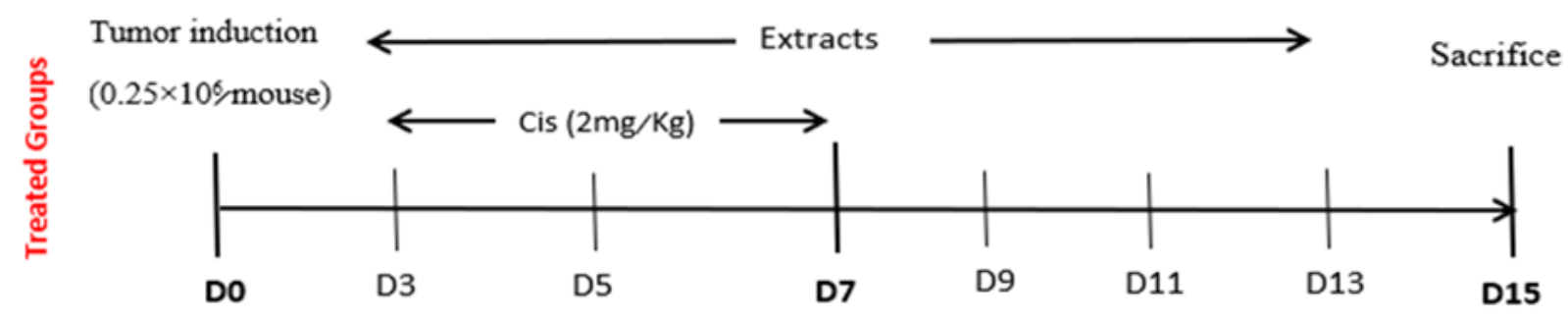

Figure 1. Experimental and plant extract treatment protocol of Cis/EAC-treated groups
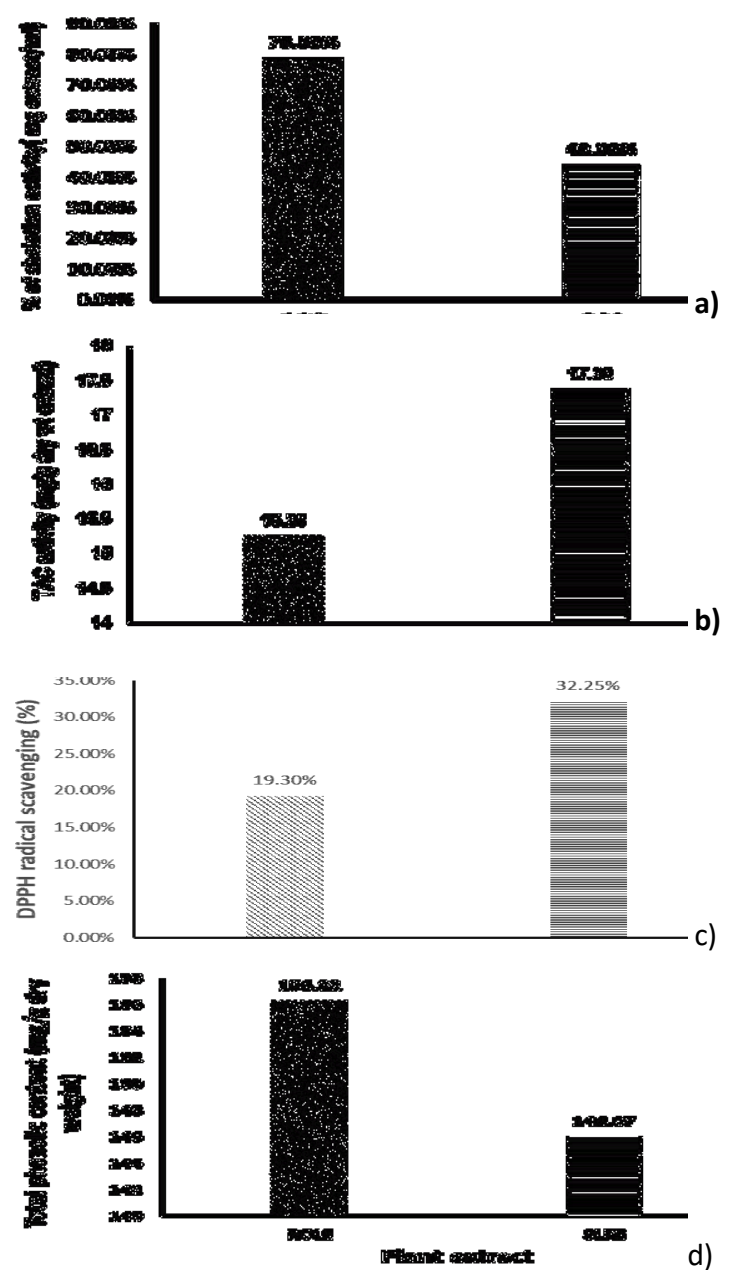

Figure 2. Metal chelation capacity (a), total antioxidant activity (b), DPPH radical scavenging activity (\%) (c) and total phenolic content (mg/g dry weight) (d) of two plant ROLE and SLRE extracts.

\section{DISCUSSION}

Breast cancer is the most common disease of all cancer types among women in the world and patients may be better off than more lethal tumors because the breast tissue is not an essential organ for human survival (Torre et al., 2015). Cyclic chemotherapy is used to effectively inhibit malignant cells and can be utilized to treat patients to generate relief, relaxation and improve the life quality of patients (Alam et al., 2018).

Present data showed that Saussurea lappa (SLRE) has a marked ability to extract antioxidant properties with higher extractive value than Rosemary officionalis (ROLE), whereas the percentage of the metal scavenging capacity of ROLE was better than SLRE. Our findings revealed that SLRE has a potent antioxidant activity than ROLE as previously showed by El-Bolkiny et al (2019) and ROLE has a better scavenging capacity (ElNaggar et al., 2016). Moreover, SLRE showed radical scavenging activity (DPPH) more than ROLE, which has a total phenolic content (TPC) more than SLRE. These levels of the antioxidant properties of both ROLE and SLRE are complementary and consistent with the results of previous investigators (Perez-Fons et al., 2010). 


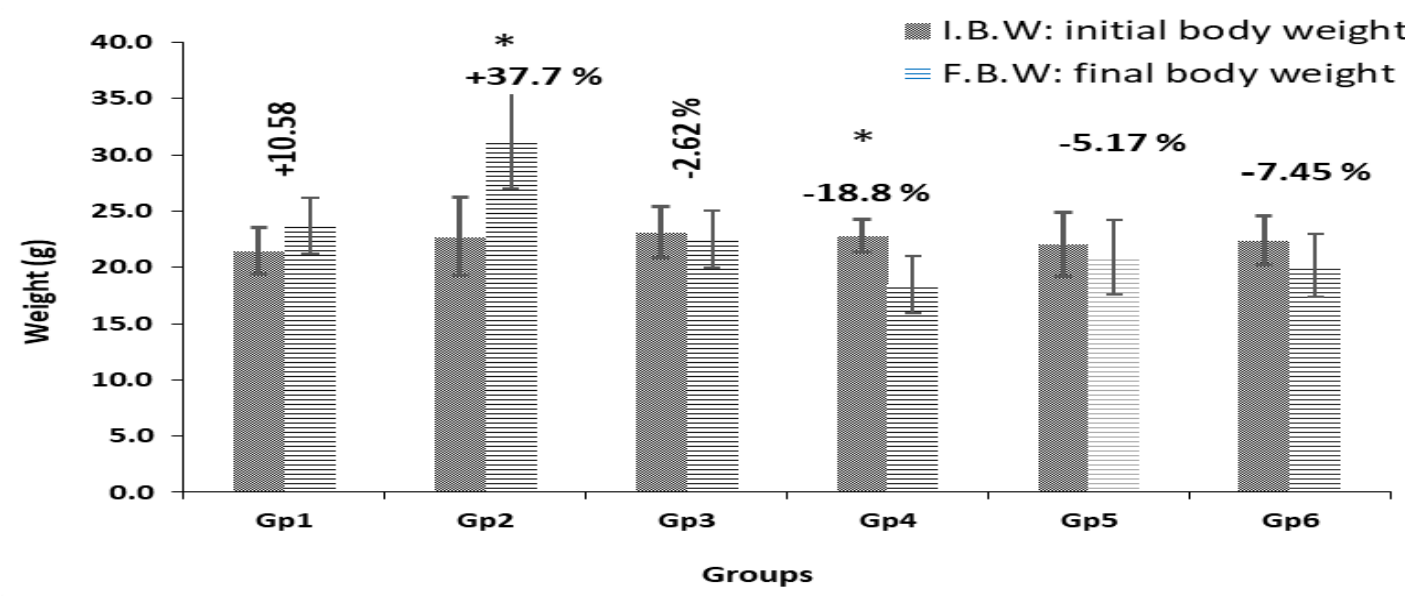

Figure 3. The initial, final body weights (g) and the percentage body weight changes in the experimental groups; Gp1: Control, Gp2: Ehrlich Ascitic Carcinoma (EAC) treated, Gp3: EAC/Cis treated, Gp4: EAC/Cis/ ROLE treated, Gp5: EAC/Cis/SLRE treated, Gp6: EAC/Cis/ROLE+SLRE treated. The obtained data were expressed as Mean \pm SD, * is statistically significant different mean at $\mathrm{P}<0.05$

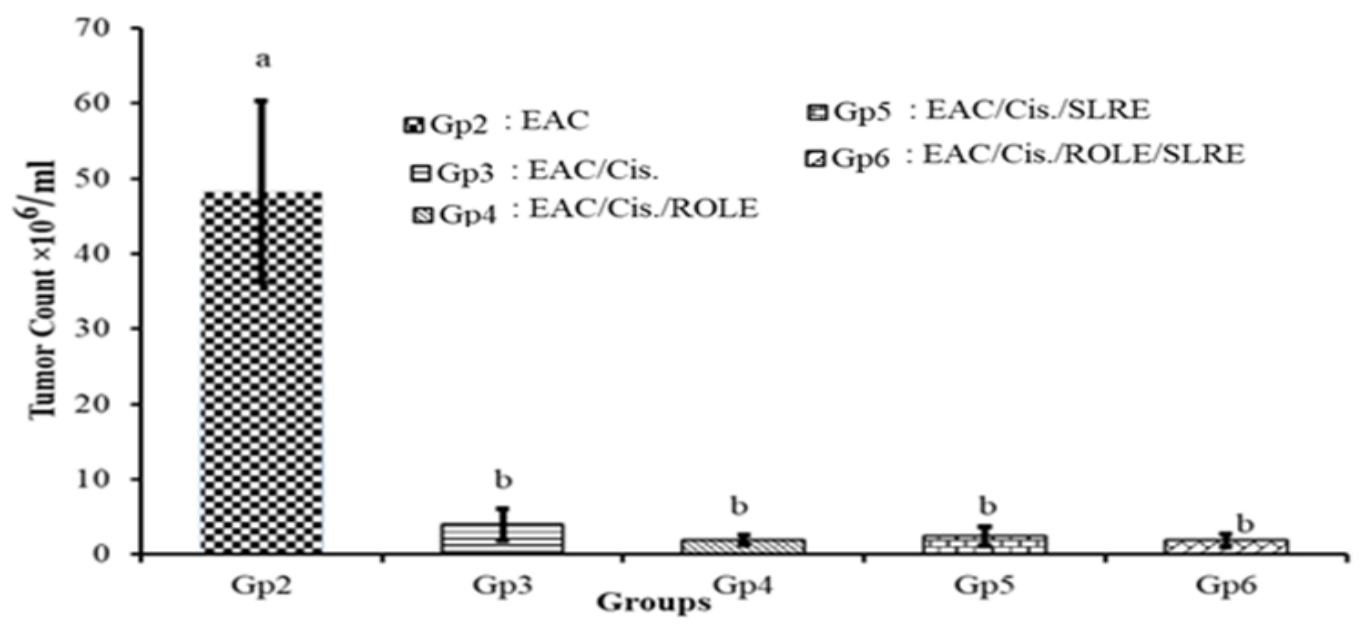

Figure 4. The total EAC cells count in different groups with different treatments under investigation. Gp2: Ehrlich Ascitic Carcinoma (EAC) treated, Gp3: EAC/Cis treated, Gp4: EAC/Cis/ ROLE treated, Gp5: EAC/Cis/SLRE treated, Gp6: $\mathrm{EAC} / \mathrm{Cis} / \mathrm{ROLE}+\mathrm{SLRE}$ treated Data are expressed as means $\pm \mathrm{SD}$. The symbols $(\mathrm{a}, \mathrm{b})$ indicate a significant change at $\mathrm{P}<0.05$ compared with $\mathrm{Gp}_{2}$ (Cis alone).

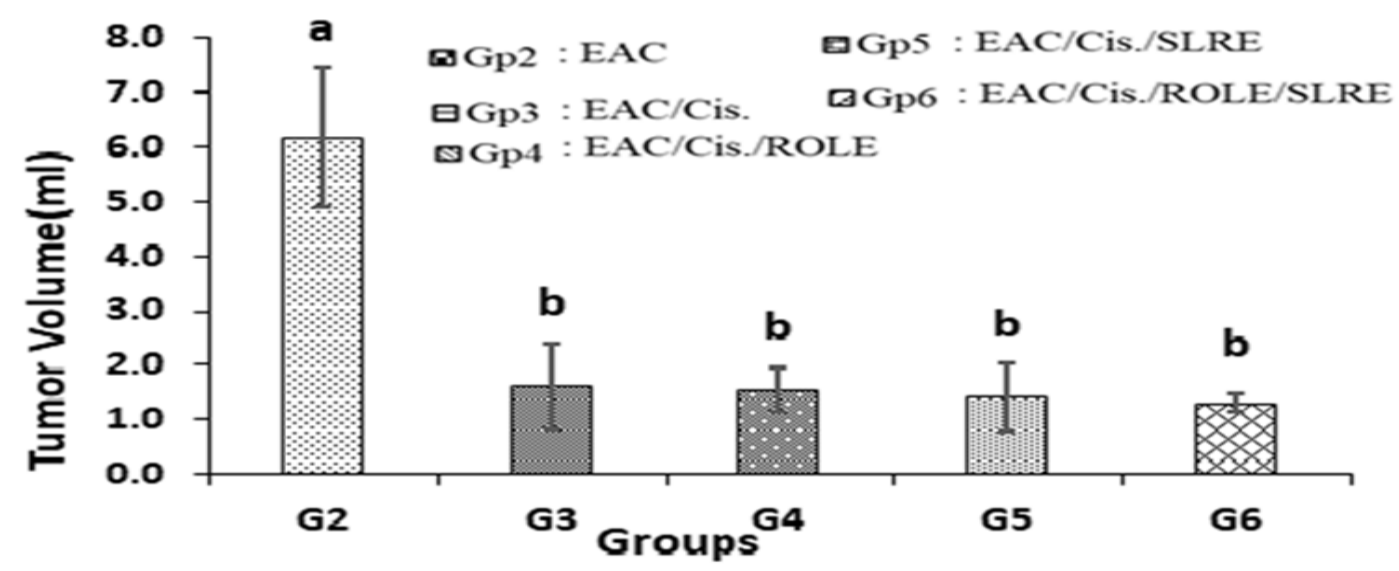

Figure 5. The total EAC volume per $(\mathrm{ml})$ in different groups with all treatments under study. Gp2: Ehrlich Ascitic Carcinoma (EAC) treated, Gp3: EAC/Cis treated, Gp4: EAC/Cis/ROLE treated, Gp5: EAC/Cis/SLRE treated, Gp6: EAC/Cis/ROLE+SLRE treated Data are expressed as means \pm SD. The symbols (b) indicate significant changes at $p<0.05$ compared with $\mathrm{G} 2$ (Cis only). 


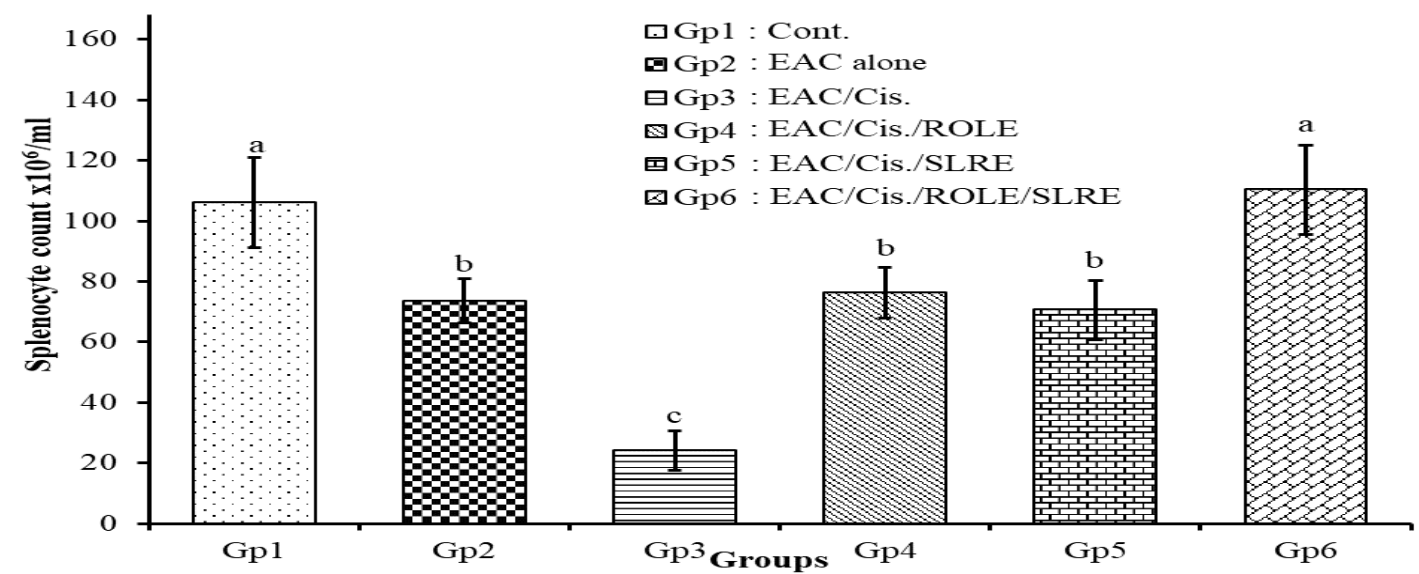

Figure 6. Total splenocytes count in different groups and treatments. Gp1: Control, Gp2: Ehrlich Ascitic Carcinoma (EAC) treated, Gp3: EAC/Cis treated, Gp4: EAC/Cis/ ROLE treated, Gp5: EAC/Cis/SLRE treated, Gp6: EAC/Cis/ROLE+SLRE treated Data are expressed as means \pm SD. The symbols $(a, b, c$.) indicate significant changes at $p<0.05$ compared to (Gp1) of naïve mice.

Current anti-tumor results showed that mice inoculated with Ehrlich ascitic carcinoma (EAC) had an increased body weight with decreased relative weights of the internal organs and this result comes to agree with Saad et al. (2017) and Saleh et al. (2020).

The treatment of EAC-mice with ROLE and SLRE in combined form improved not only the body weight but also the relative weights of the internal organs near to the control weights and these outcomes agree with those obtained by Ibarra et al. (2011).

In EAC-mice, the cell count of the tumor increased considerably because of the accumulation of ascetic fluid in the peritoneal cavity. This is attributed to either the angiogenesis observed in the peritoneal wall of the ascetic tumor or the decreased lymphatic system recovery due to the obstruction of cancer cells or lymph cells or both. Therefore, the peritoneal cavity may cause hyperpermeability of micro-blood vessels to lead to an enlargement of the abdomen (Funasaka et al., 2002). Interestingly, the present results indicated that the treatment of mice groups with ROLE or SLRE single or combined resulted in a significant reduction in the numbers of ascetic tumor cells compared to the naïve tumor group received no treatment. In the same line, cisplatin and cyclophosphamide treated mice showed a decrease in the accumulated ascetic fluid volume that may be caused by EAC inhibition (Alonso et al., 2005). In a part of this concern, El-Naggar et al. (2019) concluded that significant decreases in tumor volume, tumor cell number, and their viability compared to EAC-mice alone and EAC-mice treated with Cis were reported by EDTA cotreatment.

This conclusion was also confirmed in comparison with their control group by changes in the overall tumor volume of various groups under therapy (Ali et al., 2018).

Current results showed also that cisplatin administration to EAC-mice reduced the number of splenocytes significantly compared to the non-treated EAC-mice; the results are in accordance with the El Kholy et al. (2016). In addition, groups administered with the two extracts either ROLE or SLRE showed that the combined form if administered with cisplatin significantly increased the count of splenocytes compared to EAC-mice received cisplatin alone. In the same regard, Eldakamawy et al. (2020) stated that there was a marked disruption in spleen organization, marked loss distinction between red and white pulps, vasodilatation and congestion of spleen sinusoids in the red pulp. However, ginseng could produce a significant amelioration for these changes, a possible effective role in combining chemotherapy that prevents oxidative stress. Also, data gathered by Crăciunaş et al. (1996) and Craciun \& Pasca (2014) confirmed our results that EAC/Cis/ROLE/SLRE may be a treatment chance that revealed that splenocytes count improved around the control. 

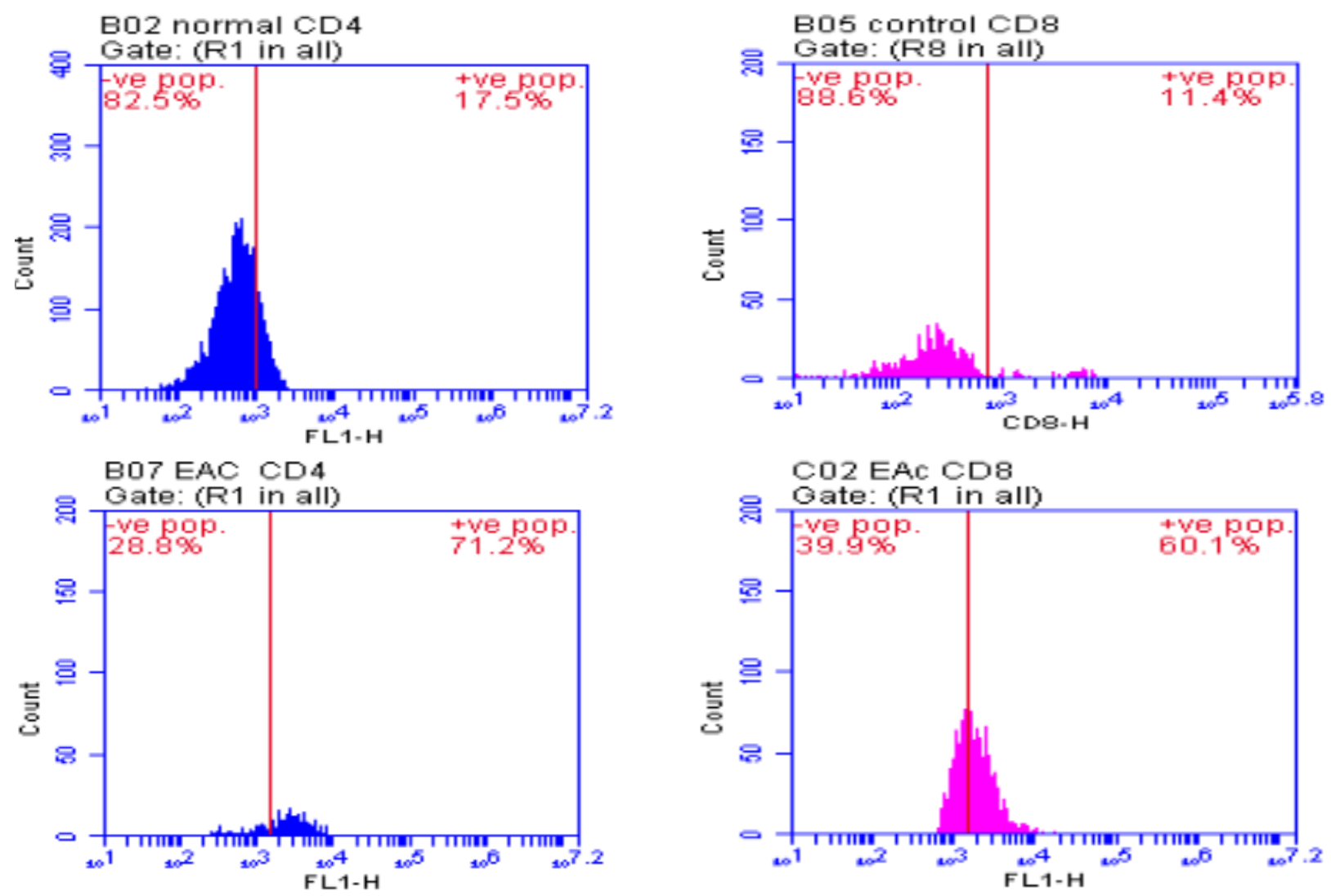

$\mathrm{CO1} \mathrm{EAC}+\mathrm{cis} C \mathrm{CD}_{4}$

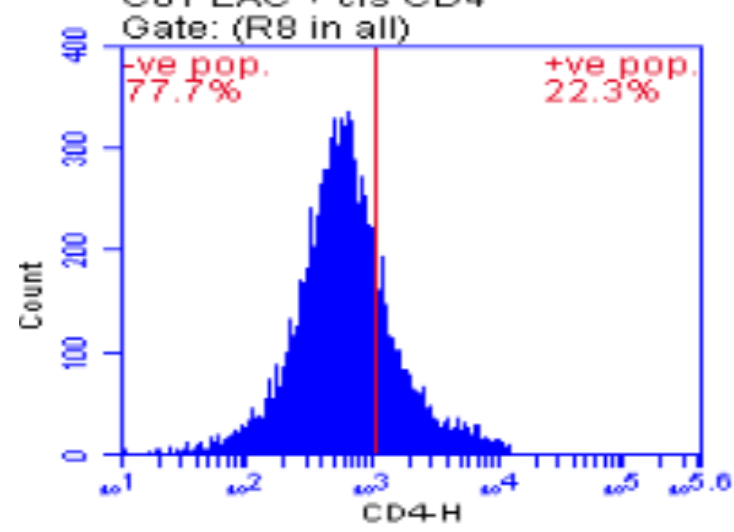

$\mathrm{BO} 4 \mathrm{EAC}+\mathrm{cis} \mathrm{CD} 8$

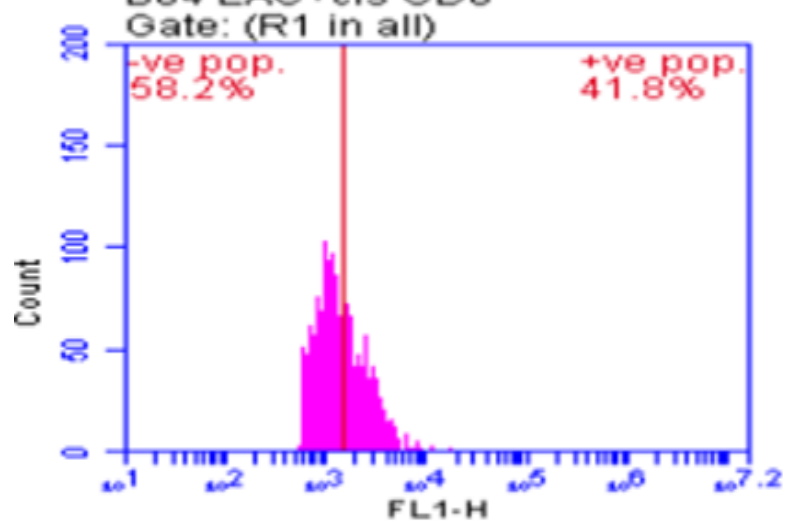

A10 treated CD4

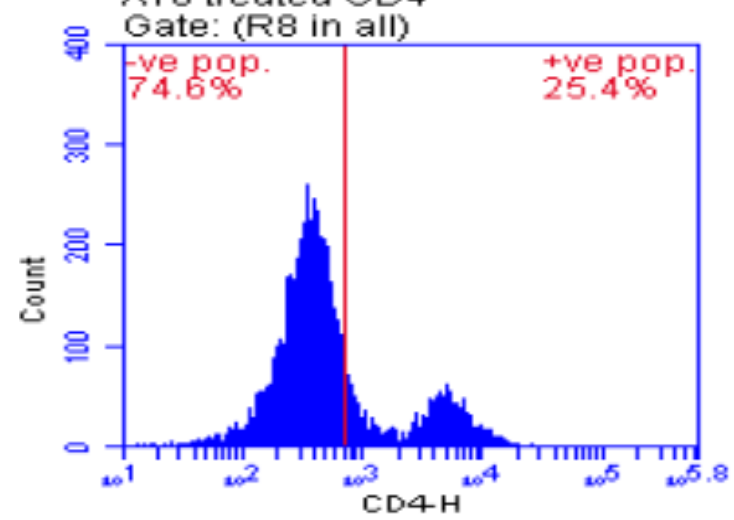

$\mathrm{BOs}$ treated $\mathrm{CDB}$

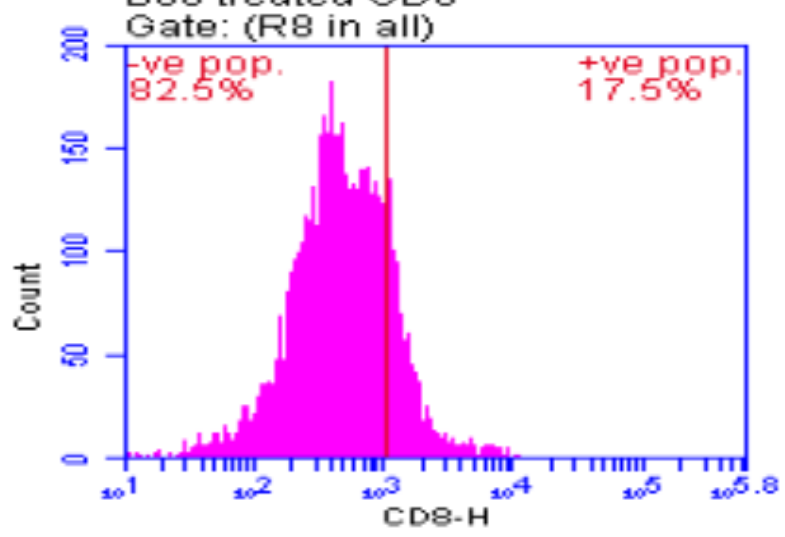

Figure 7. Representative flow cytometry analyses of $\mathrm{CD} 4^{+}$ cells gated from splenocytes of female Swiss albino mice, which orally treated with Rosemary \& costus extracts concurrent with cisplatin (D3 - D14).

Figure 8. Representative flow cytometry analyses of $\mathrm{CD} 8^{+}$ cells gated from splenocytes of female Swiss albino mice, which were orally treated with Rosemary \& costus extracts concurrent with cisplatin (D3 - D14). 
The obtained results of $C B C$ showed that no significant in the total number of RBCs, $\mathrm{Hb}, \mathrm{PCV}$ in most Cisplatin-treated EAC-bearing mice with/without plant extract either single or combined compared to naïve tumor mice.

As mentioned partly by Ahmed et al. (2019), no treatments changed the platelets count in a significant way but there is an increase in leucocyte percentage in EAC-mice compared to the control. These previous and our results are in the same line with the findings of Khorana et al. (2008). Recently, EAC-inoculation caused considerable leukocytosis, where a high number of leukocytes that linked with the initiation of cancer was found to be one of the risk indicators of venous thrombosis in cancer, which is the second cause of death in cancer as stated by Salem et al. (2020). Our finding is in the same line with Badr et al. (2011), where the total leukocytic granulocytes were significantly elevated which might be caused by inflammatory response or stress caused by EAC cell growth. Importantly, we found that treatment of EAC-mice with ROLR, SLRE or combined extract significantly alleviated the leucocytosis induced by tumor inoculation.

Current data revealed that remarkable increase in the relative neutrophil percentage in EAC group compared to the naive control. An increase in neutrophils within EAC-mice could be attributable to acute inflammatory response or stress due to EAC-cell proliferation (Mazumdar et al., 1997; Hashem et al., 2020). Our data showed that EAC-mice treated with cisplatin showed an increase in neutrophil relative percentage compared to EAC-mice alone. Treatment with both extracts concomitant with cisplatin can decrease neutrophilia induced by tumor inoculation. According to our data, EAC-mice treated with cisplatin-induced a significant decrease in the absolute number of lymphocytes compared to EAC-mice, but this observation is opposite to Salem et al. (2014). They assessed that untreated EAC-mice showed an increase of 1.1 and 1.2 , respectively in relative and absolute lymphocyte counts in relation to normal mice. In the same aspect, treatment of EAC-mice with $10 \mathrm{\mu g} /$ mouse CIS from days 7-10 induced increases in the relative and absolute numbers of lymphocytes by 1.1 and 1.3-fold, respectively compared to EAC-mice (Erian et al., 2016). Previous data revealed that the value of monocytes in tumour-bearing mice treated with $\mathrm{CIS}$ and ROLE was raised.

In flow cytometric analysis, $\mathrm{CD}^{+}$and $\mathrm{CD}^{+} \mathrm{T}$ lymphocytes were chosen in this study because of their better flowcytometrical separation compared with other types of lymphocytes (Ozsahin et al., 2005). Results showed that EACmice alone showed an increase in $\mathrm{CD}^{+} / \mathrm{CD}^{+}$ phenotypic expression and this result may explain the outcomes of Huang et al. (2015) who

estimated that the dynamics and functions of $\mathrm{CD}^{+}$and $\mathrm{CD} 8^{+} \mathrm{T}$ cells' in breast cancer etiology remain unknown. In agreement with another study by Nazir et al. (2015), the results showed that the expression of $\mathrm{CD}^{+}$and $\mathrm{CD}^{+}$was decreased after treatment of EAC-mice with CIS. The previous authors stated that cancer treatment causes structural and physiologic alterations in the vital organs of patients leading to deleterious effects, where these medications can destroy bone marrow cells and reduce the count of lymphocytes.

Fortunately, treatment of EAC/Cis-mice with both examined extracts reduced the percentage of these markers to close levels to consistent with Malaczewska (2015) and Le Guével et al. (2015) who found that Ex-vivo lymphocyte proliferative responses have been affected by administering gold nanoparticles (AuNPs) loaded with the chemotherapeutical drug. Proliferation and percentage of cells were also enhanced by the use of AuNPs coated herbal polysaccharides. An additional increase in the proliferation and percentage of $\mathrm{CD}^{+} / \mathrm{CD}^{+}$lymphocytes in EAC-mice treated with AuNPs-coated with herbal polysaccharide (Joseph et al., 2013; Lee et al., 2014). In addition, Morsi et al. (2021) demonstrated that oral iron-saturated lactoferrin administration improved tamoxifen therapy in women's breast cells in Balb/c mice to delay the appearance of tumor stability by reducing their growth. Thus the phenotypic expression of T-helper $\left(\mathrm{CD}^{+}\right.$and $\left.\mathrm{CD}^{+}\right)$cells has considerably enhanced in EAC-inoculation, and this expression may be somewhat improved by Cis therapy. The concomitant usage of both rosemary and costus combination can greatly 
enhance the natural expression of lymphocytes expression to a marked extent towards normal.

\section{CONCLUSION}

It can be concluded that concomitant administration of rosemary and costus in a combined form can improve the unhealthy effects on the $C B C$, growth rate and lymphocyte expression in cisplatin-treated tumors due to antioxidant activities of both plants.

\section{ACKNOWLEDGMENTS}

Special thanks to Dr. Khalil Mahfouz at Botany Department, Faculty of Science, Tanta University for the taxonomy work of used plants.

\section{CONFLICTS OF INTEREST}

All authors declared that there is no conflict of interest.

\section{FUND}

No fund was awarded

\section{AUTHORS' CONTRIBUTION}

The hypothesis, writing and revision were done by YE El-Bolkiny and ML Salem; experimental design and experimental design were done by for ML Salem and SA El-Nagar; Practical part and statistics are done by FR El-Sharkawy.

\section{REFERENCES}

Abdallah AAM, El-Deen NAMN, Neamat-Allah ANF, \& Abd El-Aziz HI. (2020). Evaluation of the hematoprotective and hepato-renal protective effects of Thymus vulgaris aqueous extract on thermally oxidized oil-induced hematotoxicity and hepato-renal toxicity. Comparative Clinical Pathology, 29(2): 451-461.

Agyare C, Spiegler V, Asase A, Scholz M, Hempel G \& Hensel A. (2018). An ethnopharmacological survey of medicinal plants traditionally used for cancer treatment in the Ashanti region, Ghana. Journal of Ethnopharmacology, 212:137-152.

Ahmed M, Ehab T, Ahmed SNE, Mona E M, \& Haneen HM. (2019). Antineoplastic activities of grape seed proanthocyanidin extract against Ehrlich solid tumor bearing mice induced alterations in AFP, CEA, TNF- $\alpha$ and DNA Damage. Asian Oncology Research Journal, 2(1):1-12.

Alam A, Farooq U, Singh R, Dubey VP, Kumar S, Kumari R, Kumar K, Naik BD, \& Dhar KL. (2018).
Chemotherapy treatment and strategy schemes: a Review. Journal of Toxicology, 2(5): 555600.

Alenzi, FQ, El-Bolkiny YE, \& Salem ML. (2010). Protective effects of Nigella sativa oil and thymoquinone against toxicity induced by the anticancer drug cyclophosphamide. British Journal of Biomedical Science, 67(1):20-28.

Alonso FJ, Segura JA, Lora J, Lobo C, FernándezMolina B, Márquez J, \& Matés JM. (2005). Sensitisation of Ehrlich ascitic tumour cells to methotrexate by inhibiting glutaminase. Anticancer Research, 25(5): 3315-3320.

Badr MO, Edrees NM, Abdallah AA, El-Deen NA, Neamat-Allah AN, \& Ismail HT. (2011). Antitumour effects of Egyptian propolis on Ehrlich ascites carcinoma. Veterinaria Italiana, 47(3):341-350.

Baudino AT. (2015). Targeted cancer therapy: the next generation of cancer treatment. Current Drug Discovery Technologies, 12(1): 3-20.

Bolkiny YE, Tousson E, El-Atrsh A, Akela M, \& Farg E. (2019). Costus root extract alleviates blood biochemical derangements of experimentallyinduced hypo-and hyperthyroidism in mice. Annual Research \& Review in Biology,31(5): 110.

Britt KL, Cuzick J \& Phillips KA. (2020). Key steps for effective breast cancer prevention. Nature Reviews Cancer, 20: 1-20.

Craciun C \& Pasca C. (2014). Structural and ultrastructural data on side effects of cisplatin in spleen, kidney and liver of rats. Acta Metallomica-Meemb, 11(1): 9-22.

Crăciunaş C, Crăciun C, Crăciun V, Dordea M, \& Toader-Radu M. (1996). Ultrastructural effects of certain cytostatics on rat spleen. Curr. Probl. and Techn. In Cellular and Molecular Biology, 1: 311-317.

El-Bolkiny YE, Al-Shurbagi IK, Nassef MNM and ElSayed MA. (2021). Intake of $\omega-3$ fatty acids reduces obesity in mice through augmentation of lipid oxidation and thyroid signaling, and prevention of anemia. International Journal of Cancer and Biomedical Research, (in press).

El-Bolkiny YE. (2006). Influence of Black seed (Nigella sativa I) oil and its active ingredient Thymoquinone on Cyclophosphamide-induced toxicity in male albino rats. The Eegyptian Journal of Experimental Biology (zoology), 2: 221-232.

El-Naggar SA, Abdel-Farid IB, Germoush MO, Elgebaly HA, \& Alm-Eldeen AA. (2016). Efficacy of Rosmarinus officinalis leaves extract against cyclophosphamide-induced hepatotoxicity. Pharmaceutical Biology, 54(10): 2007-2016. https://doi.org/10.3109/13880209.2015.1137 
954

El-Naggar SA, El-Said KS, Mobasher M\& Elbakry M. (2019). Enhancing antitumor efficacy of cisplatin low dose by EDTA in Ehrlich ascetic carcinoma bearing mice. Brazilian Archives of Biology and Technology, 62: e19180716.

El Kholy S, Salem M, Al-Atrash A, \& Samy D. (2016). Tumor burden and cisplatin treatment alter the expression levels of microRNA-146a and -155 in spleen and cancer cells in an experimental mouse model of Ehrlich ascite carcinoma. Journal of Solid Tumors, 6(1): 78-86 https://doi.org/10.5430/jst.v6n1p

Eldakamawy S, Hafez E, Basuony M, Fatoh SA, \& Tousson E. (2020). Protective role of ginseng root aqueous extract administration on antineoplastic drug cisplatin-induced spleen oxidative stress and injury. Asian Oncology Research Journal, 20-30.

Erian NS, Hamed HB, El-Khateeb AY, \& Farid M. (2016). Effect of Crude Aqueous Extracts of Some Medicinal Plant Flowers on Solid Ehrlich Tumor in Mice. The Arab Journal of Sciences \& Research, 2(5): 22-34.

Funasaka T, Haga A, Raz A, \& Nagase H. (2002). Tumor autocrine motility factor induces hyperpermeability of endothelial and mesothelial cells leading to accumulation of ascites fluid. Biochemical and Biophysical Research Communications, 293(1): 192-200.

Geran RI, Greenberg NH, Macdonald MM, Schumacher AM.(1972). Protocols for screening chemical agents and natural products against animal tumors and other biological systems. Natl Cancer Inst., Bethesda, Md, 3 (2):1-107.

Ghosh S. (2019). Cisplatin: The first metal based anticancer drug. Bioorganic Chemistry, 88, 102925.

Hashem MA, Mahmoud EA, \& Abd-Allah NA. (2020). Alterations in hematological and biochemical parameters and DNA status in mice bearing Ehrlich ascites carcinoma cells and treated with cisplatin and cyclophosphamide. Comparative Clinical Pathology, 29(2): 517-524.

Huang $Y$, Ma C, Zhang Q, Ye J, Wang F, Zhang Y, Hunborg $P$, Varvares MA, Hoft DF \& Hsueh EC. (2015). CD4+ and CD8+ T cells have opposing roles in breast cancer progression and outcome. Oncotarget, 6(19): 17462.

Ibarra A, Cases J, Roller M, Chiralt-Boix A, Coussaert A, \& Ripoll C. (2011). Carnosic acid-rich rosemary (Rosmarinus officinalis L.) leaf extract limits weight gain and improves cholesterol levels and glycaemia in mice on a high-fat diet. British Journal of Nutrition, 106(8): 1182-1189. Joseph MM, Aravind SR, Varghese S, Mini S \&
Sreelekha TT. (2013). PST-Gold nanoparticle as an effective anticancer agent with immunomodulatory properties. Colloids and Surfaces B: Biointerfaces, 104: 32-39.

Kailnde MA, Gomaa SB, \& Mahmoud MO. (2020). The effect of some natural antioxidants against cisplatin-induced neurotoxicity in rats: behavioral testing. Heliyon, 6(8): 4708. https://doi.org/https://doi.org/10.1016/j.heliy on.2020.e04708

Khorana AA, Kuderer NM, Culakova E, Lyman GH \& Francis CW. (2008). Development and validation of a predictive model for chemotherapy-associated thrombosis. Blood, 111(10): 4902-4907.

Kunimura C, Kikuchi K, Ahmed N, Shimizu A, \& Yasumoto S. (1998). Telomerase activity in a specific cell subset co-expressing integrin $\beta 1 / E G F R$ but not p75 NGFR/bcl2/integrin $\beta 4$ in normal human epithelial cells. Oncogene, 17(2): 187-197.

Le Guével X, Palomares F, Torres MJ, Blanca M, Fernandez TD \& Mayorga C. (2015). Nanoparticle size influences the proliferative responses of lymphocyte subpopulations. RSC Advances, 5(104):85305-85309.

Lee $\mathrm{CH}$, Syu SH, Chen YS., Hussain SM, Onischuk AA, Chen WL \& Huang GS. (2014). Gold nanoparticles regulate the blimp1/pax 5 pathway and enhance antibody secretion in Bcells. Nanotechnology, 25(12): 125103.

Malaczewska J. (2015). The splenocyte proliferative response and cytokine secretion in mice after oral administration of commercial gold nanocolloid. Polish Journal of Veterinary Sciences, 18(1): 181-189.

Mazumdar UK, Gupta M, Maiti S, \& Mukherjee D. (1997). Antitumor activity of Hygrophila spinosa on Ehrlich ascites carcinoma and sarcoma-180 induced mice. Indian Journal of Experimental Biology, 35(5): 473-477. http://europepmc.org/abstract/MED/9378516

Minotti G, \& Aust SD. (1987). An investigation into thee mechanism of citrateFE2+-dependent lipid peroxidation. In Free Radical Biology and Medicine, 3(6): 379-387. https://doi.org/10.1016/0891-5849(87)900165

Morsi D, Salem ML, Ibrahim H, Osman G, Mohamed A \& Nofal A. (2021). Synergistic and chemosensitizing effects of bovine lactoferrin or muramyl dipeptide in Ehrlich solid tumorbearing mice treated with cisplatin. International Journal of Cancer and Biomedical Research, 5(1): 75-94.

Nazir T, Islam A, Omer MO, \& Mustafa M. (2015). Lymphocytopenia; induced by vinorelbine, 
doxorubicin and cisplatin in human cancer patients. Breast Disease, 35(1): 1-4. https://doi.org/10.3233/BD-140386

Oun R, Moussa, YE, \& Wheate NJ. (2018). The side effects of platinum-based chemotherapy drugs: a review for chemists. Dalton Transactions (Cambridge, England: 2003), 47(19): 66456653. https://doi.org/10.1039/c8dt00838h

Ozsahin M, Crompton NEA, Gourgou S, Kramar A, Li L, Shi Y, Sozzi WJ, Zouhair A, Mirimanoff RO \& Azria, D. (2005). CD4 and CD8 T-lymphocyte apoptosis can predict radiation-induced late toxicity: a prospective study in 399 patients. Clinical Cancer Research : An Official Journal of the American Association for Cancer Research, 11(20): 7426-7433. https://doi.org/10.1158/1078-0432.CCR-042634

Perez-Fons L, Garzon MT, \& Micol V. (2010). Relationship between the antioxidant capacity and effect of rosemary (Rosmarinus officinalis L.) polyphenols on membrane phospholipid order. Journal of Agricultural and Food Chemistry, 58(1): 161-171.

Prasanna R, Ashraf EA, \& Essam MA. (2017). Chamomile and oregano extracts synergistically exhibit antihyperglycemic, antihyperlipidemic, and renal protective effects in alloxan-induced diabetic rats. Canadian Journal of Physiology and Pharmacology, 95(1): 84-92.

Prieto P, Pineda M \& Aguilar M. (1999). Spectrophotometric quantitation of antioxidant capacity through the formation of a phosphomolybdenum complex: Specific application to the determination of vitamin $\mathrm{E}$. In Analytical Biochemistry, 269(2): 337-341. https://doi.org/10.1006/abio.1999.4019

Saad EA, Hassanien MM, El-Mezayen HA, \& ELmenawy NM. (2017). Regression of murine Ehrlich ascites carcinoma using synthesized cobalt complex. MedChemComm, 8(5): 11031111.

Saleh MA, Antar SA, Hazem RM \& El-Azab MF. (2020). Pirfenidone and Vitamin D Ameliorate Cardiac Fibrosis Induced by Doxorubicin in Ehrlich Ascites Carcinoma Bearing Mice: Modulation of Monocyte Chemoattractant Protein-1 and Jun N-terminal Kinase-1
Pathways. Pharmaceuticals, 13(11): 348.

Salem ML, Kadima AN, El-Naggar SA, Rubinstein MP, Chen Y, Gillanders WE \& Cole DJ. (2007). Defining the ability of cyclophosphamide preconditioning to enhance the antigenspecific CD8+ T-cell response to peptide vaccination: creation of a beneficial host microenvironment involving type I IFNs and myeloid cells. Journal of Immunotherapy, 30(1): 40-53.

Salem ML, Talat S \& El-Barbary A. (2014). Immunomedulatory effects of single and combinatorial anti-cancer chemotherapy in a tumor mouse model. Egyptian Journal Experimental Biologyl, (1) 41-46.

Salem ML, Mona MM, Ziada M, \& Bassiony MA. (2020). Potential antitumor effects of egg extract and purple fluid from marine Aplysia fasciata against experimental Ehrlich ascites carcinoma. International Journal of Cancer and Biomedical Research, 4(3): 229-241.

Ali SMO, Eldesoky ERN, Salahuddin MA, \& Eisa MN. (2018). Atorvastatin ameliorates cisplatin induced oxidative stress in ehrlich ascites solid tumor-bearing mice: a prospective case control study. Al-Azhar Medical Journal, 47(1): 97-107.

Schoch S, Gajewski S, Rothfuß J, Hartwig A, \& Köberle B. (2020). Comparative study of the mode of action of clinically approved platinum-based chemotherapeutics. International Journal of Molecular Sciences, 21(18): 6928.

Seidler SJ, \& Huber DE. (2020). Overview of Diagnosis and Treatment of Breast Cancer in Young Women. EC Gynaecology SI, 2: 18-25.

Sorsa M., Hemminki K \& Vainio H. (1985). Occupational exposure to anticancer drugspotential and real hazards. Mutation Research/Reviews in Genetic Toxicology, 154(2): 135-149.

Tai J, Cheung S, Wu M \& Hasman D. (2012). Antiproliferation effect of Rosemary (Rosmarinus officinalis) on human ovarian cancer cells in vitro. Phytomedicine, 19 (5): 436-443.

Torre LA, Bray F, Siegel RL, Ferlay J, Lortet-Tieulent J \& Jemal A. (2015). Global cancer statistics 2012. CA: A Cancer Journal for Clinicians, 65(2): 87-108. 